\title{
Erratum to: Cloning and molecular modelling of pectin degrading glycosyl hydrolase of family 28 from soil metagenomic library
}

\author{
T. A. Sathya - Ani Methew Jacob - Mahejibin Khan
}

Published online: 6 May 2014

(C) Springer Science+Business Media Dordrecht 2014

\section{Erratum to: Mol Biol Rep (2014) 41:2645-2656 \\ DOI 10.1007/s11033-014-3123-8}

In the paper by T. A. Sathya, Ani Methew Jacob, Mahejibin Khan entitled "Cloning and molecular modelling of pectin degrading glycosyl hydrolase of family 28 from soil metagenomic library" in "Material and methods" section, under "Enzyme characterization" it is mentioned that " $\mathrm{pH}$ stability of the enzyme was determined by incubation of the enzyme in $0.1 \mathrm{M}$ sodium acetate buffer of varying $\mathrm{pH}$ (2-9)". This is corrected as " $\mathrm{pH}$ stability of the enzyme was determined by incubation of the enzyme in $0.1 \mathrm{M}$ (Glycine $\mathrm{HCl}$ buffer, $\mathrm{pH}$ 2; Sodium acetate buffer $\mathrm{pH} 3-5$; Phosphate buffer, $\mathrm{pH} 6-8$; and borate buffer $\mathrm{pH} 9.0$ )". This error does not affect any of the conclusions regarding stability of enzyme at different $\mathrm{pH}$.

The online version of the original article can be found under doi:10.1007/s11033-014-3123-8.

T. A. Sathya · A. M. Jacob · M. Khan ( $\square)$

Department of Food Microbiology, CSIR-Central Food

Technological Research Institute, Mysore 570020, India

e-mail: mahejibin@cftri.res.in

T. A. Sathya - M. Khan

Academy of Scientific \& Innovative Research,

New Delhi 110001, India 